\title{
Contributions of Aníbal Quijano and Enrique Dussel for an Anti-Management Perspective in Defence of Life *
}

\author{
Contribuciones de Aníbal Quijano y Enrique Dussel para una perspectiva anti-gestión en defensa de la vida \\ Contribuições de Aníbal Quijano e Enrique Dussel para uma Perspectiva Anti-Management em Defesa da Vida
}

\author{
Maria Ceci Araujo Misoczky ${ }^{\text {a }}$ \\ Universidade Federal do Rio Grande do Sul, Brasil \\ maria.ceci@ufrgs.br \\ ORCID: http://orcid.org/0000-0003-2020-5882
}

DOI: https://doi.org/10.11144/Javeriana.cao32-58.caqed Redalyc: http://www.redalyc.org/articulo.oa $? \mathrm{id}=20560207009$

Date received: $03 / 07 / 2018$

Date accepted: 29/03/2019

Date published: 30/06/2019

\begin{abstract}
:
In this essay, I argue for the need of a critical dialogue with the field of Postcolonial Studies considering, among other features, its tendency to neglect the study of contemporary forms of political domination and economic exploitation. A tendency that is even more present in the field of Organization Studies, which has been increasingly colonized by management. This text is located within the field of Latin American studies, adopting Dussel's Philosophy of Liberation and its ethical fundament as references. I also argue for the adoption of an anti-management attitude because the distinction between Northern/Southern management is irrelevant for the victims, for those suffering material impoverishment, forced to premature death, lack of dignity and a host of injustices.
\end{abstract}

JEL Codes: D23, M19, O20, F54

Palabras clave: Aníbal Quijano, Enrique Dussel, Philosophy of Liberation.

\section{Resumen:}

En este ensayo, defiendo la necesidad de un diálogo crítico con el campo de los estudios poscoloniales, considerando, entre otros aspectos, su tendencia a descuidar el estudio de las formas contemporáneas de dominación política y explotación económica. Una tendencia aún muy presente en el campo de los Estudios Organizacionales, que ha sido colonizada cada vez más por la administración. Este texto hace parte de los estudios latinoamericanos, adopta la filosofía de la liberación de Dussel y sus fundamentos éticos como referencia. Asimismo, defiendo la adopción de una actitud anti-management porque la distinción entre management del Norte y del Sur es irrelevante para las víctimas, para aquellos que sufren un empobrecimiento material, quienes se ven obligados a muertes prematuras, a falta de dignidad y a un sinnúmero de injusticias.

Códigos JEL: D23, M19, O20, F54

Palabras clave: Aníbal Quijano, Enrique Dussel, filosofía de la liberación.

\section{Resumo:}

Neste ensaio, argumento pela necessidade de um diálogo crítico com o campo dos Estudos Pós-Coloniais considerando, entre outros aspectos, sua tendência para negligenciar o estudo de formas contemporâneas de dominação política e exploração econômica. Uma tendência que ainda está mais presente no campo dos Estudos Organizacionais, que tem sido crescentemente colonizado pelo management. Este texto se localiza no campo dos estudos Latino-Americanos, adotando a Filosofia da Libertação de Dussel, e seus fundamentos éticos, como referência. Eu também argumento pela adoção de uma atitude anti-management porque a distinção entre management do Norte e do Sul é irrelevante para as vítimas, para aqueles que sofrem empobrecimento material, são forçados a mortes prematuras, falta de dignidade e a um conjunto de injustiças.

Códigos JEL: D23, M19, O20, F54

Palavras-chave: Aníbal Quijano, Enrique Dussel, filosofia da libertação.

Author notes: 
For some of us, this call for papers is an opportunity to revisit previous writings and ideas, to critically assess our own contribution and to move forward considering contemporary debates. As a Latin American, it is impossible to avoid a situated way of approaching the theme. However, this impossibility is not only due to the geopolitical locus of enunciation, ${ }^{[1]}$ it has to do with the fact that Latin American intellectuals have forged an epistemic space from the colonial difference. As Coronil (2008, p. 414) indicates, "critical responses to colonialism from different locations take different but complementary forms". From a Latin American perspective, "it has become indispensable to globalize the periphery, to recognize the worldwide formation of what appears to be self-generated modern metropolitan centres and backward peripheries".

What I am introducing is the need of a critical dialogue with the field of Postcolonial Studies considering, among other features, its tendency to neglect the study of contemporary forms of political domination and economic exploitation. A tendency that is even more present in the field of Organization Studies -OS-, which has been increasingly colonized by management. In the words of Misoczky, Flores and Goulart (2015, p. 131), under the Anglo-Saxon construct of Management and Organization Studies -MOS-,

any research that does not contribute to the practice of management is considered outside the field; the study of the organization of social struggles is considered irrelevant; and critical management studies ends up being an oxymoron - the critical dimension is jeopardized by the impossibility of negating management and contributing to management; among others. (Misoczky, Flores, \& Goulart, 2015, p. 131)

By taking this context into account, I can now locate this text within the field of Latin American studies adopting the Philosophy of Liberation ${ }^{[2]}$ (Dussel, 2015) and its ethical fundament as references. Therefore, I need to introduce the material principle of ethics that "concerns, in the last instance, the production, reproduction and development of human life in community - a content that has universal validity and determines all levels of the formal moral" (Dussel, 2004, pp. 344-345). Finally, I argue for the adoption of an anti-management attitude because the distinction between Northern/Southern management is irrelevant for the victims, for "those suffering material impoverishment, forced to premature death, lack of dignity and a host of undeserved injustices" (Dussel, 2013, p. 291). In other words, the material universal criterion presented above denies the validity of capitalism as a system because it systematically generates victims, it also denies the validity of all knowledge that has practical-operational functions for its production and reproduction. ${ }^{[3]}$

The option for Quijano's coloniality of power and Dussel's transmodernity is justified because they open possibilities for a politicized discussion that goes beyond culturalism and indicates the need of transcending the globalized capitalist power as an indispensable condition for the liberation of the victims of this system of power. Influenced by these perspectives, follows a critical appraisal of Postcolonial Studies and a brief overview of its presence in the field of MOS. Finally, the argument of this essay is for the need of an anti-management perspective that could contribute to liberate at least part of OS from the colonialism of management and, at the same time, express our co-responsibility, as academics and activists, with the liberation of the victims of the prevailing system.

In Latin America, a ground-breaking formulation came from the thought and the pen of Anibal Quijano, a Peruvian sociologist and humanist thinker known for having developed the concept of coloniality of power. I will introduce part of this seminal contribution in his own words, based on a text first published in 1992, when the commemoration of 500 years of the invasion of America was taking place.

What is termed globalization is the culmination of a process that began with the constitution of America and colonial/ modern Eurocentred capitalism as a new global power. One of the fundamental axes of this model of power is the social classification of the world's population around the idea of race, a mental construction that expresses the basic experience of colonial domination and pervades the more important dimensions of global power, including its specific rationality: Eurocentrism. The racial axis has a colonial origin and character, but it has proven to be more durable and stable than the 
colonialism in whose matrix it was established. Therefore, the model of power that is globally hegemonic today presupposes an element of coloniality. (Quijano, 2000, p. 533)

In a previous text, Quijano (1991) introduces the concept of coloniality to refer to the structures of control and hegemony that emerged from colonialism, stretching from the conquest of America to the present. In other words, coloniality is a term that encompasses the transhistoric expansion of colonial domination and its effects in contemporary times. It facilitates "an understanding of how race and labour were articulated in the colonial period -a subject often neglected in Postcolonial Studies- and of its perpetuation in modern times" (Moraña, Dussel, \& Jáuregui, 2008, p. 9).

For Quijano (2000, pp. 533-534), "America was constituted as the first space/time of a new model of power of global vocation, and both in this way and by it became the first identity of modernity" based on two fundamental axes. One is the idea of race: "a supposedly different biological structure that placed some in a natural situation of inferiority to the others". On this basis, the conquistadores classified the population of America, and later the world. The other process "was the constitution of a new structure of control of labour and its resources and products" that expressed "an articulation of all historically known previous structures of control of labour - slavery, serfdom, small independent commodity production and reciprocity - together around and upon the basis of capital and the world market".

With America, "an entire universe of new material and intersubjective relations was initiated". Therefore, the concept of modernity accounts for the changes in the material dimensions of social relations (i.e., world capitalism, coloniality of power) and for the changes that occur on all levels of social existence. In other words, "starting with America, a new space/time was constituted materially and subjectively: this is what the concept of modernity names" (Quijano, 2008, p. 195).

It is interesting to observe how Quijano's analysis shares similarities with Marx (1976) description of the historical process that gave birth to the preconditions of capitalism development, involving the subordination of populations from the South and from the North to the world market/economy. For his location at the centre of capitalism, Marx was not able to recognize the role of the racial division of labour (as Quijano did), but he was able to identify how European capitalism needed to dominate and exploit indiscriminately of the people's location. He analysed the expulsion of the peasants from new enclosures, a process that created, in the centre, massive sections of population divorced from their means of production that, with no other means of livelihood, had to compulsorily sell their labour power to the nascent industries. Dialectically, in the periphery,

the discovery of gold and silver in America, the extirpation, enslavement and entombment in mines of the indigenous population of the continent, the beginning of the conquest and plunder of India, the conversion of Africa into a preserve for the commercial hunting of black-skins, all of this characterized the dawn of the era of capitalist production. (Marx, 1976, p. 915)

Back to Quijanos's propositions, what we have is an approach that connects modernity and capitalism because capitalist determinations required a material and intersubjective social process that "could not have a place except within social relations of exploitation and domination” (Quijano, 2008, p. 198). It also defines Eurocentrism as a specific rationality or perspective of knowledge that was made globally hegemonic as an indispensable part of these determinations. Accordingly, it is a wider perspective that goes beyond the epistemological dimension, connecting it with concrete relations of power because it was "the instrumentalization of the reasons for power, of colonial power in the first place, which produced distorted paradigms of knowledge and spoiled the liberating promises of modernity". Of course, epistemological decolonization is needed to clear the way for new intercultural communication, "for an interchange of experiences and meanings, as the basis of another rationality which may legitimately pretend to some universality". However, it cannot be achieved without "the destruction of the coloniality of world power" as "part of the process of social liberation from all power organized as inequality, discrimination, exploitation, 
and as domination" (Quijano, 2007, pp. 177-178). If coloniality is constitutive of modernity, the rhetoric of modernity and the logic of coloniality cannot be separated. Therefore, the rhetoric of progress, salvation, technology, and democracy goes hand in hand with the practices of oppression, racial discrimination, and the concentration of political and economic power.

To summarize, coloniality is a neologism created to make sense of a constitutive feature of modernity which cannot be thought of outside the context of Eurocentric hegemonic patterns of knowledge and its claims of universality. This supposed universalism is what justifies the so called 'civilizing missions': first seen in Christianization, then in the myth of progress and modernization, still associated with the powerful symbolic carrier of promises of a better life (development). As a consequence, the study of coloniality implies

the challenge of thinking across (frontiers, disciplines, territories, classes, ethnicities, epistemes, temporalities) in order to visualize the overarching structure of power that has impacted all aspects of social and political experience in Latin America since the beginning of colonial era. (Moraña, Dussel \& Jáuregui, 2008, p. 17)

Quijano's contribution indicates two directions simultaneously. One is analytical - the concept of coloniality opens up space 'for the reconstruction and the restitution of silenced histories, repressed subjectivities, subalternized knowledge and languages'. The other is programmatic - it indicates the need for de-coloniality of power and knowledge (Mignolo, 2007, p. 451). In order to improve this argument, I introduce Enrique Dussel's proposal of a transmodern project.

As part of the critical debate on postmodernity and postmodernism, Dussel (1998) claims for a double movement: on the one hand, the appropriation of modernity; on the other, the move towards transmodernity. This movement is understood as a liberating strategy that includes both the colonizer and the colonized. It does not mean the refusal of reason, but the critique of violent, coercive and genocide reason. In Dussel's (2001, p. 69) words: "We do not deny the rational nuclei of the universalist rationality of Enlightenment, only its irrational moment as sacrificial myth. We do not deny reason, just the irrationality of the violence generated by the myth of modernity". Based on this assumption, he proposes a dialogue that would include discourses and practices from the perspective of the Other excluded, the non-Eurocentric alterity, allowing the transcendence of modernity by a transmodern world in which both, modernity and the denied alterity co-construct a process of mutual creative fertilization.

The project of a transmodern world includes a pluriversal episteme that goes beyond Eurocentric ethnocentrism to create a situated and dialogical knowledge based on diverse locations and perspectives and, at the same time, addresses certain core universal problems that are present in all places and cultures. In other words, the refusal of the Eurocentric universality claim does not imply the refusal of any universal claim: the transmodern project expresses the need of a universal common shared project against capitalism, patriarchy, imperialism and coloniality. As a project, transmodernity allows for the understanding of the emergence of cultures which had been historically depreciated and unvalued not as a miracle arising from nothingness, but rather as a return of these cultures to their status as world-actors. The liberating moment of modernity implies the recognition of Alterity, of this Other who ratifies and proves its existence and allows for the construction of a transmodern world. It expresses a utopian horizon as a new age of the world "beyond the postulations of modernity, capitalism, Eurocentrism and colonialism". An age in which "the requirements of the existence of life on earth demanded a new ontological attitude regarding the existence of nature, labour, property and diverse cultures". It is also an age in which, thanks to the new economic relations that would overcome capitalism, "there will be no exploitation of the most vulnerable" in the name of profit (Dussel, 2015, p. 100).

Both Quijano and Dussel followed the political and dialectical scope of dependency theory, and this is a very important aspect because it allows them to go beyond epistemic/knowledge coloniality and to firmly inscribe their propositions in concrete relations of exploitation and domination that manifest themselves 
in multiple ways, such as social hierarchies, racial discrimination, economic exploitation, gender violence, cultural subordination, and the destruction of nature.

Having briefly presented the propositions of these authors, I will introduce some critical reflections on the project of Postcolonial Studies.

'Post-colonialism' as a term and a conceptual category originated as part of the process of independence struggles of African and Asian colonies after the II World War to characterize changes in the states and economies of ex-colonies of the so-called 'Third World'. Although Latin America was part of the Third World, because most of its nations had achieved political independence during the first part of the XIX Century, it has not been included. This is a first criticism of the idea of post-colonialism. Another one is that from the historical perspective, we cannot ignore that colonialism is still a concrete reality and that the desire of autonomy still informs the lives of many people around the world (maybe the more evident cases are Puerto Rico and Palestine.

Around three decades after the II World War, the second usage of the term 'postcolonial' was developed in the Anglophone world in connection with critical studies of colonialism and colonial literature, under the influence of postmodern and poststructuralist perspectives. Let us remember the historical context in which it happened: "the breakdown of really existing socialism; the ascendance of conservative politics in Britain (Thatcherism and the United States (Reaganism; and the overwhelming appearance of neoliberal capitalism as the only visible, or at least seemingly viable, historical horizon". As part of this context, Postcolonial Studies abandoned any perspective regarding the possibility of liberation from the material conditions of oppression. Another aspect to consider is that its distinctive identity as an academic field is "marked by the unusual marriage between the metropolitan location of its production and the anti-imperial stance of its authors, many of whom were linked to the Third World by personal ties and political choices". In this phase, "while historical work has centred on British colonialism, literary criticism has focused on Anglophone texts, including those from Australia and the English-speaking Caribbean” (Coronil, 2013, pp. 3-4).

Contemporary Postcolonial Studies encompass problems as different as the formation of minorities in USA and African philosophy. But, while it expanded towards new areas, it retreated from analysing their relations within a unified field, stressing on the study of parts, following the scepticism towards any grand narrative and "not always discriminating between Eurocentric claims to universality and the necessary universalism arising from struggles against world-wide capitalist domination” (Coronil, 2013, p. 4).

Grafoguel (2014) defends the need of decolonizing Postcolonial Studies. His main argument relates to the fact that modernity did not start at the mid XVIII Century with British colonialism in India -as Spivak and Babha consider-, nor at XIX Century when Napoleon arrived in Egipt -as Said considers-, but in 1492. According to him, the consequences of the invasion of America are constitutive of the European colonial expansion to India and the Arab world. There are also epistemic traps in these criticized assumptions, which include the acceptance of the emancipatory logic inner to the Enlightenment modern project. Following these misunderstandings, it is easy to understand the acritical inclusion of poststructuralism as their main reference. Besides, the privilege of epistemology over the sources of real colonial expressions allows the presentation of their provincial readings as if they were universal.

Consequently, some have asked What is the relation between the state of the field and the state of the world? This is a very needed reflection, considering that the consolidation of the field of Postcolonial Studies happened between the end of the cold war and 9/11, a period in which the prospect of negotiated processes, such as the ones of South Africa and Northern Ireland, may have led to the belief of the possibility of thinking after colonialism. However, as the world changed with the post-9/11 return to expansionist imperial policies, we should also address the failures of Postcolonial Studies (Wenzel, 2007, p. 633).

Homi Bhabha (2004, p. xviii) wrote, in his foreword to a new translation of Frantz Fanon's The Wretched of the Earth, that postcolonial academics have been distracted by the wrong politics, focusing "perhaps too 
exclusively on the culture wars, the politics of identity, and the politics of recognition". This is an interesting quote, because the depoliticized celebration of hybrid identities and cultural flows often took Bhabha's work as a point of departure (Wenzel, 2007).

Other errors and misunderstandings of Postcolonial Theory/Studies can be highlighted: i) an epistemic error - the confusion of postcolonial theory and the condition of postcoloniality, dividing "between the narrative of the other in the European narrative and the people who live in the other places -the Global South- who cannot claim to be the other" (Wenzel, 2007, p. 635); ii) it is Anglocentric, it does not make sense to literary and cultural scholars outside English, and it "focused so exclusively on northern European colonialism that it ended up looking at colonialism through provincial eyes"; iii) it celebrates "fragments disconnected from structures" and cultural constructs are "seen independently of the mundane conditions that made them possible" (Coronil, 2007, p. 637); iv) it fails to account for the foundational literary texts of the colonial experience and to engage with literatures produced in indigenous language (Wenzel, 2007); v) it fails to address and understand African studies that "underscores issues of continuity, not discontinuities, resurgences and posts", that "emphasize concrete historical processes to pay attention to the violence, cultural and political domination, as well as economic domination of colonial and postcolonial rule", instead of the central reference to textuality, discursive practices and the construction of subjectivities and identities (Diouf, 2007, p. 640).

To summarize, the field focused so exclusively on northern European colonialism, mostly anglophone, that "it ended up looking at colonialism through provincial eyes" and neglecting other colonialisms. Informed by fashionable 'turns' and 'posts' of the 1980s, the field focused on fragments of the colonial past, unable to examine present postcolonial empires as changing imperialist formations (Coronil, 2007, p. 637). It also ignores the existing colonies and contemporary neo-colonial practices, such as the new enclosures organized by transnational extractive industries (mega-mines and large-scale monoculture tree plantations, for example).

A view of colonialism as starting from the XV century "would offer a different understanding of modern colonialism and colonial modernity". Some obvious landmarks, besides the invasion of America, would be: 1804 Haiti's political independence, 1825 continental Latin America's political independence, and 1947 India's political independence. Also, if we could recognize that 9/11 names not only 2011 but also 1973 Chile's overthrown of Salvador Allende by an USA-backed coup, "we would be better prepared to place the post 9/11 resurgent imperialism in a larger imperial landscape”. Expanding the field's temporal and spatial referents - bringing not only Latin America, but also Africa into a discussion that has been too Anglocentric, can potentially transform the conceptual categories and, mainly, connect fragments to wholes, the discursive to the material, and local narratives to grand narratives (Coronil, 2007, p. 627).

In the words of Said (2012), when divorcing himself from the field, "postcolonialism had become a 'misnomer' that did not sufficiently recognize the persistence of neocolonialism, imperialism, and structures of dependency". Unless we escape culturalism and epistemologicism, decolonization remains a metaphor that makes possible a set of evasions that problematically attempt to reconcile settler guilt and complicity, and rescue settler futurity (Tuck \& Yang, 2012). To avoid it, we must take into consideration present and material imperialist, colonial and neo-colonial social, economic and political relations. We also need to have some ethical-normative principle to avoid the erasure of moral references that are part of poststructuralist or postcolonial theories and studies, avoiding "the abandonment of serious engagements with the fundamental question of human value" (Diouf, 2007, p. 639).

As I mentioned in the beginning of this essay, the universal material principle enunciated by Dussel (2004) can fill this void. The criterion of the reproduction and development of human life, which is internal to each culture, allows each of them to be self-critical regarding intrinsic moments which prevent life. It also allows the dialogue among cultures taking into consideration what is valid or invalid for the production, reproduction and development of human life in community. 
So, what about postcolonialism and Management and Organization Studies -MOS-, a field that has been so committed with colonial and imperial practices from nation-states and transnational corporations? A review published in 2011 identifies the main trends until then (Jack, Westwood, Srinivas, \& Sardar, 2011, concluding that the two principal foci are knowledge and identity. Despite the recognition, made by the authors, that any review of this type does not address accounts that are not published in English and do not show up in standard literature searches, it is worthy to review it, among other reasons because they are an evidence of the relations of dominance that pervade cognitive capitalism. The authors also recognize that, when referring to attempts to articulate indigenous, non-Western and context-sensitive accounts of management and organization, it is noticeable that many of those accounts that are published in English and in international publishing houses have been constructed by Western scholars speaking on behalf of the other in non-Western contexts - reproducing a problematic characteristic of Postcolonial Studies. Some issues addressed in the field have been comparative and cross-cultural management; specific domains included marketing, tourism, diversity management, political risk assessment, and management control.

It is also recognizable the selective way in which Postcolonial Theory has been incorporated in the field of MOS. On the one hand, postcolonial organizational analysts have very much relied upon the 'Holy Trinity' of Said, Bhabha and Spivak as resources to engage in textual/discourse-based critiques, maybe as a consequence of the fascination with language and its constitutive effects that came with the interest in poststructuralism (Jack, 2015. On the other hand, for the domain of Critical Management Studies, and its conferences, Anglocentrism is a notable feature.

Among the earliest deployments of postcolonial references, it is worthy to mention the work of Frenkel and co-authors, which included the identification of hybrid patterns of knowledge developed in Israel after British and US models of productivity were incorporated (Frenkel \& Shenhav, 2003; the deployment of Bhabha's propositions and his notion of a 'third space' to address intercultural encounters and to explore knowledge transfer within the context of multinational corporations (Frenkel, 2008; the study of developing and emerging multinational corporations identifying barriers to reverse colonialist hierarchies and showing how emerging firms play the free market game of the North (Frenkel, 2014.

Another frequently mentioned author is Prasad (1997 and his concern to analyse and challenge the 'diversity industry' in business and management. In another work, he provides an overview of the natures, development and negative effects of Eurocentrism, including the use by Western researchers of readily available stereotypes in theorizing non-Western cultural, economic, political and other institutions and practices. In this book, Prasad (2012 is interested in providing new directions for the theory, research and practice of management.

Just with the purpose of illustrating the argument, some other examples are mentioned here. Adopting the notion of a 'third space', Seremani and Clegg (2016 introduce the indigenous theory of Southern Africa, Ubuntu, discussing its interaction with more conventional Western management and organization theory. Kaasila-Pakanen (2015 investigates multiculturalism as an instrument of control deeply connected to broader institutionalized power structures, resulting in a series of researches that are incapable of addressing the complex realities of cultural encounters in which identities and otherness are constructed. Ul-Haq and Westwood (2012 discuss the under- and mis-representation of Islamic management and organization in the literature, arguing for the persistence of essentialism and orientalism, the disposition to refract instances of Islamic Management and Organization Knowledge through Northern lenses, and the tendency for some Southern scholars and institutions to become intellectually captive to the North's knowledge system. Srinivas (2012 proposes an alternative Indian-centred management approach, discussing two quests for authenticity based in claims of epistemic relevance and performative efficacy. Ruggunan (201Gitgues that the engagement in critical historiographies of South African management studies and its allied disciplines unpacks the ways in which disciplinary knowledge is produced over time and challenges the view of management-studies knowledge as universal and apolitical. Kamoche and Siebers (2015 address Chinese 
management practices in Kenya, looking for a better understanding of the types of incompatibilities that prevent the development of appropriate business and human resources practices.

These examples indicate the same trend we find in Postcolonial Studies: the celebration of fragments and cultural constructs. There is also a predominant focus on means to perfect management practices and theories. As a result, the hybridism between MOS and postcolonialism ends up being very functional to the reproduction of a global systemic order based on violence, cultural and political domination, and economic exploitation. Other examples of the disconnection of the coloniality of knowledge and the coloniality of power are studies that look for the reversal of colonialist hierarchies of knowledge in the management of transnational corporations, without considering the role of these corporations in the coloniality of power and new imperial practices.

In my interpretation, the influence of postcolonial ideas in the field of MOS is a renewal of the persistent trend of domesticated critique (Misoczky \& Amantino-Andrade, 1995) in which the concrete material relations that produce and reproduce domination and exploitation remain obscured. Within the limits of the hermeneutic critique it is possible to address epistemic subordination without addressing the material dimensions inscribed in the coloniality of power. However, as Quijano $(1991,2000)$ clearly indicates, epistemological decolonization is indispensable, but it is not feasible without the destruction of the coloniality of a world power that is systemically organized in concrete social relations of production.

In the Latin American OS context, the formal introduction of the topic of coloniality can relate to the publication, in the same year, of two articles that share similar approaches. Ibarra-Colado (2006) discusses the tendency of OS in Latin America towards falsification and imitation of the knowledge generated in the Centre and proposes a preliminary research agenda, built from original approaches that recognize otherness, to appreciate the organizational problems of Latin America. With the same culturalist emphasis, but focusing mainly in the Brazilian context, Misoczky (2006) asserts the need of decolonizing OS by taking into consideration the peculiarities of specific locus of enunciation and avoiding non-reflexive reproductions of representations developed in the Centre.

Misoczky and Dornelas-Camara (2015) review these contributions and criticize their naïve assumption that the academic practice in a field under the domination of management can be transformed by merely changing its relationship with the knowledge produced in the Centre. It is also mentioned the inadequate transposition of Dussel's contributions, in a substantialist reading that leaves aside the material content and addresses merely the subordinated attitude of the participants in the academic institutionalized system. Therefore, the locus of enunciation is taken as the criterion for judging the validity of knowledge production, instead of the consequences for the production of victims by a system in which OS dominated by management play an indispensable role. The authors also illustrate the consequences of this understanding with the work of Faria and Wanderley (2013a, 2013b) on the strategic decolonization of family enterprises. Another example of the use of Quijano and Dussel's propositions removing all traces of the political radical critique that is at the basis of these authors oeuvre - a practice not uncommon in the field of MOS -, is the article by Alcadipani and Faria (2014, p. 114) addressing the possibilities of "co-creation of a truly international field of international business".

It is necessary to remember what was stated in the beginning of this essay regarding an anti-management attitude. Without taking this position into consideration, the critiques of postcolonialism, of its presence in the field of MOS, and of the misappropriation of Quijano and Dussel's propositions by some Latin American scholars of this field may look as an exercise of pure arrogance or, at least, of bad mood.

My argument is that the possibilities, announced by Misoczky, Flores and Goulart (2015), of producing counter-hegemonic knowledge in an academic space still dominated by management knowledge and, worst, by its current managerialist expression, can be strengthen by the dialogue with the coloniality of power and the philosophy of liberation. However, it is not enough to denounce the dominance of management (again, no matter if Southern management or Northern management ${ }^{[4]}$ ), it is necessary to open spaces within the 
field of OS to include struggles against the impacts of business and management in the production and reproduction of people's lives and livelihoods and to the processes embodied in these struggles as indications of prefigurative politics and organization.

This challenge demands the co-responsibility for the liberation of the victims of the prevailing system and transversal dialogues with the difference. More specifically, it demands the articulation of our knowledge production with the knowledge produced as part of the critical praxis of popular organization(s which includes, among others, feminist struggles, the defence of threatened ways of living in connection with the defence of nature, the confrontation of racism in all its forms, the emergence of silenced indigenous voices and practices, the protection of immigrants, peasants and workers movements.

The negation of oppression begins with the affirmation of the exteriority of the Other. In the face-toface encounters with the community of human life that expresses the Other, we can opt for solidarity and responsibility. However, this is not merely a subjective or charitable encounter. This responsibility includes the analysis and the denounce of the structures and processes that make it impossible for the victims to produce and reproduce their life in community, in the clear knowledge that the victims always have the original historical and concrete ethical consciousness. Therefore, "only those who have some 'experience' of an 'us' against the domination can reflexively think about the un-happiness of the Other: it is the thematic critique (scientific and philosophical, but both critical" (Dussel, 2004, p. 356.

Following this indication, Misoczky and Böhm (2015 present the meaning of the ethics of liberation for us, academics:

Acting as organic intellectuals, it is this explicit thematic critique that we, from our position, can elaborate. Thematic critical consciousness consists of three moments: an ethical-critical consciousness of the oppressed, which is pre-thematic but substantively original; a thematically explicit consciousness; and an existential thematic critical consciousness. From that latter moment, it becomes possible the construction of new collectives, including the oppressed and academic organic intellectuals. (Misoczky, \& Böhm, 2015, p. 71)

Dussel (1974) also proposes a methodology of liberation, which he names as 'analectics' - an attitude that expresses the openness to think, to listen, to see, to feel, to taste the world from the perspective of the Other; it is conditioned by humbleness and solidarity. Analectics allows one to recognize the existence of a politics of Totality and the Other. The "politics of the Other is an anti-politics, it is a politics of subversion and contestation", since it challenges established hierarchies and legal truths. It proclaims the injustice and illegitimacy of the actual system in the name of a new legitimacy (Mendieta, 2001, p. 21), that of the community of victims. Alcoff (2011, p. 67) defines analectics as "an epistemology for the new revolution": a decolonized epistemology that puts "at the centre not simply the objective conditions of global impoverishment and oppression, but the systematic disauthorization of the interpretive perspective of the oppressed". The idea of analectics is driven to a "more comprehensive and more adequate understanding of all that is true concerning the experience of those whose experiences are most often ignored" (Alcoff, 2011, p. 71$)$.

This attitude would help to overcome the fact that "OS has remained relatively blind to the processes of organizing and the knowledge produced in the organizational practices from below" (Misoczky et al., 2017, p. 250) and still tends to reproduce, in the study of social movements, the structural bias that obscures and suppresses the key political and economic dimensions.

As we mentioned before, Dussel (2009) does not deny reason and rationality. Instead, he includes rationality in the ethical principle of liberation that affirms the need of critical feasible interventions, and critical interventions demand organization. Dussel (2004, p. 353) defends the need of an instrumentalstrategic reason in the ethical praxis of liberation: "we cannot fall into fetishisms; we cannot ignore the subaltern function of instrumental reason". The problem resides when the feasibility criterion becomes an absolute principle. Dussel (2004, p. 353) provides a description of the principle of the ethical feasibility: 
An action, an institutional or systemic norm, is ethically operational and concretely feasible if it complies (a) with the logical, empirical, technical, economic, etc., conditions, the possibility of which is judged by the following (b) [deontic] requirements: (b.1) ethical-material practical truth, and (b.2) formal-moral validity; within a range that goes from (b.a) actions ethically allowed (which are merely possible because they do not contradict ethical and moral principles), until (b.b) mandatory actions, which are 'necessary' for the actualization of basic human needs (materially - the reproduction and development of life; formally - the participation of the affected by the decision-making). (Dussel, 2004, p. 353)

Here we have the centrality of organization, indispensable when the oppressed feel their life is threatened and their critical consciousness awakens. As Freire (2005, p. 85) indicates, organizational praxis comes from consciousness (conscientização), when people apprehend their situation as "a historical reality susceptible to transformation". With it, comes the need to organize, to make decisions based on critical-strategic reasoning which is expressed in many popular struggles:

From the positivity of the ethical principle of life, from the negativity of materially risking death, and from the absence of power in relation to the institutional (corporate and governmental) power, the victims realize the non-validity of the system, experience being a people, confront the actual valid consensus and elaborate the formal intersubjective consensus of the oppressed. In the process of building this consensus, the people elaborate a new project, a future validity that will guarantee life and will be collective at political and organizational dimensions. (Misoczky \& Böhm, 2015, p. 84)

I can now summarize the main points of this essay, starting with the importance of appropriating the contributions of organic intellectuals who dedicated their lives and oeuvres to confront the system that oppresses and constantly generates victims, while honoring, not betraying, their political positions. This is not always easy in a field of studies in which we are constantly asked to provide contributions at the service of perfecting practices of oppression and exploitation: management. It is not easy, but it is not impossible either. Exercises of intellectual honesty based on by ethical principles would easily make it possible, no matter in which field of academic practice.

The insistence of Aníbal Quijano in the dialectical precedence of coloniality of power over epistemic coloniality is a clear indication of the insufficiency of culturalist approaches, which are prevailing in the field of OS. In that sense, it is easy to understand the last fashion in the boom of Postcolonial Studies, a fashion that contributes to silence the inconvenient negative critique that defines critical Latin American thought. In another episode of ideas out-of-place (Schwarz, 1992), now under the rubric of a postcolonialism, what we find is the renewal of the imitative and inauthentic character of our academic life.

Certainly, the path we choose is always a political choice. In that sense, this is not only a positioned paper, but an obviously very political one. Having chosen the responsible solidarity with the community of victims informed by Dussel's philosophy and ethics of liberation, I share with many academics of our field the commitment with the people who put their lives at risk to confront the global pattern of capitalist power. This commitment includes the negative critique of OS colonized by management (no matter if under fashionable apparently critical positions) and the aim of co-constructing relevant and meaningful knowledge for the activists and for their organizational practices. By adopting an analectical attitude, we find ourselves in the Freirean dialectics of denouncing and announcing (Freire, 2005): in the negative act of denouncing the dehumanizing structure of power and the practices that sustain and reproduce it (such as management) in dialogue with the communities of the oppressed; and in the positive utopian moment of announcing what can realistically be done because it is constantly experienced in popular transformative struggles.

\section{References}

Alcadipani, R., \& Faria, A. (2014). Fighting Latin American marginality in 'international' business. Critical Perspectives on International Business, 10(1-2), 107-117.

Alcadipani, R., \& Reis Rosa, A. (2011). From global management to glocal management: Latin American perspectives as a counter-dominant management epistemology. Journal of the Administrative Sciences, 28(4), 453-466. 
Alcadipani, R., Khan, F., Gantman, E., \& Nkomo, S. (2012). Southern voices in management and organization knowledge. Organization, 19(2), 131-143.

Alcoff, L. (2011). An epistemology for the next revolution. Transmodernity: Journal of Peripheral Cultural Production of the Luso-Hispanic World, 1(2), 67-78.

Bhabha, H. (2004). Foreword: Framing Fanon. In F. Fanon. The wretched of the earth (pp. vii-xiii), New York: Grove.

Coronil, F. (2007). Editor's column: The end of Postcolonial Theory? A Roundtable with Sunil Agani, Fernando Coronil, Gaurav Desai, Mmadou Diouf, Simon Gikandi, Sutie Tharu, and Jenniver Wenzel. PMLA, 122(3), 633-651.

Coronil, F. (2008). Elephants in the Americas? Latin American Postcolonial studies and global decolonization. In M. Moraña et al. (eds.), Coloniality at large: Latin America and the Postcolonial Debate (pp. 396-416), Durham: Duke University Press.

Coronil, F. (2013). Latin American Postcolonial Studies and global decolonization. Worlds \& Knowledge Otherwise, Spring. Recuperado el 15 de mayo de 2018, de https://pdfs.semanticscholar.org/6c71/cb02a4aba7a9dc7b9af4 81c6eca4d55e07d7.pdf.

Diouf, M. (2007). Editor's column: The end of Postcolonial Theory? A Roundtable with Sunil Agani, Fernando Coronil, Gaurav Desai, Mmadou Diouf, Simon Gikandi, Sutie Tharu, and Jenniver Wenzel. PMLA, 122(3), 633-651.

Dussel, E. (1974). Metodología para una filosofía de la liberación. Salamanca: Sígueme.

Dussel, E. (1998). Beyond Eurocentrism: The world-system and the limits of modernity. In F. Jameson \& M. Miyoshi (eds.), The cultures of globalization (pp. 3-31), Durham: Duke University Press.

Dussel, E. (2001). Eurocentrismo y modernidad. En W. Mignolo (comp.), Capitalismo y geopolitica del conocimiento: el eurocentrismo y la filosofía de la liberación en el debate intelectual contemporáneo (pp. 57-70), Buenos Aires: Signos.

Dussel, E. (2004). Hacia una arquitectónica de la ética de la liberación. En K.-O. Apel, \& E. Dussel. Ética del discurso yética de la liberación (pp. 339-366), Madrid: Trotta.

Dussel, E. (2009). Una nueva edad en la historia de la filosofía: el diálogo mundial entre tradiciones filosóficas. Tabula Rasa, 11, 97-114.

Dussel, E. (2011). From critical theory to the philosophy of liberation, Transmodernity: Journal of Peripheral Cultural Production of the Luso-Hispanic World, 1(92), 16-43.

Dussel, E. (2012). Transmodernity and interculturality: An interpretation from the perspective of philosophy of liberation'. Transmodernity: Journal of Peripheral Cultural Production of the Luso-Hispanic World, 1(3), 28-59.

Dussel, E. (2013). Ethics of liberation in the age of globalization and exclusion. Durham: Duke University Press.

Dussel, E. (2015). Filosofías del sur: descolonización y transmodernidad. México D. F.: Akal.

Faria, A., \& Wanderley, S. (2013a). Fundamentalismo da gestão encontra a descolonialidade, repensando estrategicamente organizações familiares. Cadernos EBAPE.BR, 11(1), 569-587.

Faria, A., \& Wanderley, S. (2013b). Organizações familiares "otherwise”. III Colóquio Internacional de Epistemologia e Sociologia da Ciência da Administração. Florianópois.

Freire, P. (2005). Pedagogy of the oppressed. New York: The Continuum International Publishing Group.

Frenkel, M. (2008). The Multinational corporation as a third space: Rethinking international management discourse on knowledge transfer through Homi Bhabha. Academy of Management Review, 33(4), 924-942.

Frenkel, M. (2014). Can the periphery write back? Periphery-to-centre knowledge flows in multinationals based in developing and emerging economies. In R. Westwood et al. (eds.), Core-periphery relations in organization studies (pp. 33-52). Basingstoke: Palgrave-Macmillan.

Frenkel, M., \& Shenhav, Y. (2003). From Americanization to colonization: The diffusion of productivity modes revisited. Organization Studies, 24, 1537-1561.

Ibarra-Colado, E. (2006). Organization studies and epistemic coloniality in Latin America: Thinking otherness from the margins. Organization, 13(4), 463-488. 
Jack, G. (2015). Postcolonial theory: speaking back to empire. In R. Mir et al. (eds.), The Routledge companion to philosophy in organization studies (pp. 151-170). London: Routledge Companions.

Jack, G., Westwood, R., Srinivas, N., \& Sardar. Z. (2011). Deepening, broadening and re-asserting a postcolonial interrogative space in organization studies. Organization, 18(3), 275-302.

Kaasila-Pakanen, A.-L. (2015). A postcolonial deconstruction of diversity management and multiculturalism. In R. Bendl et al. (eds.), The Oxford handbook of diversity in organizations (pp. 175-194). Oxford: Oxford University Press.

Kamoche, K., \& Siebers, L. (2015). Chinese management practices in Kenya: Toward a post-colonial critique. International Journal of Human Resource Management, 26(21), 2718-2743.

Marx, K. (1976). Capital, vol. I. London: Penguin.

Mendieta, E. (2001). Política en la era de la globalización: crítica de razón política de E. Dussel. En E. Dussel. Hacia una filosofía politica crítica (pp. 15-39), Bilbao: Desclée de Brouwer.

Mignolo, W. D. (2007). Delinking: the rhetoric of modernity, the logic of coloniality and the grammar of decoloniality. Cultural Studies, 21(2-3), 449-514.

Mignolo, W. D. (2008). The geopolitics of knowledge and the colonial difference. In M. Moraña et al. (eds.), Coloniality at large: Latin America and the Postcolonial Debate (pp. 125-258), Durham: Duke University Press.

Misoczky, M. C. (2006). Sobre o centro, a crítica e a busca da liberdade na práxis acadêmica. Cadernos EBAPE.BR, $4(3), 1-13$.

Misoczky, M. C., \& Amantino-de-Andrade, J. (2005). Uma crítica à crítica domesticada nos estudos organizacionais. Quem tem medo do fazer acadêmico enquanto práxis? Revista de Administração Contemporânea, 9(1), 193-212.

Misoczky, M. C., \& Böhm, S. (2015). The oppressed organize against mega-mining in Famatina - Argentina: Enrique Dussel's ethics of liberation. In A. Pullen \& C. Rhodes (Orgs.) The Routledge companion to ethics, politics and organizations (pp. 67-84). London: Routdeldge.

Misoczky, M. C., \& Dornelas-Camara, G. (2015). Enrique Dussel: contribuições para a crítica ética e radical nos estudos organizacionais. Cadernos EBAPE.BR, 13(2), 286-314.

Misoczky, M. C., Dornelas-Camara, G., \& Böhm, S. (2017). Organizational practices of social movements and popular struggles: understanding the power of organizing from below. Qualitative Research in Organizations and Management, 12(4), 250-261.

Misoczky, M. C., Flores, R. F., \& Goulart, S. (2015). An anti-management statement in dialogue with critical Brazilian authors. Revista de Administração de Empresas, 55(2), 130-138.

Moraña, M., Dussel, E., \& Jáuregui, C. (2008). Colonialism and its replicants. In M. Moraña et al. (eds.), Coloniality at large: Latin America and the Postcolonial Debate (pp. 1-20). Durham: Duke University Press.

Prasad, A. (1997). The colonizing consciousness and representation of the Other: A postcolonial critique of the discourse of oil. In A. Prasad et al. (eds.), Managing the organizational meltingpot: dilemmas of workplace diversity (pp. 285-311), Thousand Oaks: Sage.

Prasad, A. (2012). Working against the grain: advances in postcolonial organization studies. Malmo: Copenhagen Business School Press.

Quijano, A. (1991). América, el capitalismo y la modernidad nacieron el mismo día. ILLA: Revista del Centro de Educación y Cultura, 10, $42-57$.

Quijano, A. (2000). Coloniality of power, Eurocentrism, and Latin America. Nepantla: Views from the South, 1(3), 533-580.

Quijano, A. (2007). Coloniality and modernity/rationality. Cultural Studies, 21(2-3), 168-178.

Quijano, A. (2008). Coloniality of power, eurocentrism and social classification. En M. Moraña et al. (eds.), Coloniality at large: Latin America and the Postcolonial Debate (pp. 181-224). Durham: Duke University Press.

Ruggunan, S. D. (2016). Decolonising management studies: A love story. Acta Commercii, 16(2), 103-138.

Said, E. W. (2002). A conversation with Neeldari Bhattacharya, Suvir Kaul, and Ania Loomba. In D. Goldberg et al. (eds.), Relocating Postcolonialism (pp. 1-14). Oxford: Blackwell. 
Schwarz, R. (1992. Misplaced ideas: essays on Brazilian culture. London: Verso.

Seremani, T., \& Clegg, S. (2016. Postcolonialism, organization, and management theory: the role of "epistemological third spaces". Journal of Management Enquiry, 25(2, 171-183.

Srinivas, N. (2012. Epistemic and performative quests for authentic management in India. Organization, 19(2, 45-158.

Tuck, E., \& Yang, K. (2012 Decolonization is not a metaphor. Decolonization: Indigeneity, Education \& Society, 1(1, $1-40$.

Ul-Haq, S., \& Westwood, R. (2012. The politics of knowledge, epistemologic occlusion, and Islamic management and organizational knowledge. Organization, 19(2, 229-257.

Wenzel, J. (2007. Editor's column: The end of Postcolonial Theory? A Roundtable with Sunil Agani, Fernando Coronil, Gaurav Desai, Mmadou Diouf, Simon Gikandi, Sutie Tharu, and Jenniver Wenzel. PMLA, 122(3), 633-651.

\section{Notes}

* Research paper.

[1] According to Mignolo (2008), the locus of enunciation refers to the disciplinary, geocultural and ideological space from which discourses are elaborated.

[2] "Philosophy of Liberation set out from the locus enuntiationis of the material victim, from the negative effect of authoritarianism, capitalism and patriarchy. However, this is the root of a profound divergence with Critical Theory that continues up to the present..., that of the material negativity of colonialism..., a phenomenon which corresponds to metropolitan capitalism, Modernity, and Eurocentrism" (Dussel, 2011, p. 17). "Latin American philosophy, as Philosophy of Liberation, discovered its cultural conditioning (since it understood itself from the perspective of a determinate culture), but, moreover, it was articulated (explicitly or implicitly) from the perspective of the interests of determinate classes, groups, genders, races, etc." (Dussel, 2012, p. $32)$.

[3] "The 'content' of ethics (the reproduction and development of life) has, abstractly, its own universality and always materially determines all levels of formal ethics. The 'formal' aspect of moral (the right, richtig), the level of universal intersubjective validity (Gültigkeit), abstractly and formally determines all levels of material ethics. It is a situation of constantly presenting mutual determination with different meanings (one is 'material'; the other is 'formal'). This is a fundamental thesis of the ethics of liberation, because in such a way it is possible to ethically interpret the materiality... as an a priori of all critique (a negative critique which departs from the 'absence' of material actualization of the subjects, namely the impossibility of living, unhappiness, suffering... of the victims)" (Dussel, 2004, p. 344).

[4] On this kind of distinction see, for example, Alcadipani and Reis Rosa (2011), and Alcadipani, Khan, Gantman, \& Nkomo (2012).

\section{Licencia Creative Commons CC BY 4.0}

How to cite: Misoczky, M. C. (2019). Contributions of Aníbal Quijano and Enrique Dussel for an antimanagement perspective in defence of life. Cuadernos de Administración, 32(58). https://doi.org/10.1114 4/Javeriana.cao32-58.caqed 